UDC 330.101

JEL Classification: 21, 122, 011

http://doi.org/10.21272/mmi.2019.1-06

Serhiy Shkarlet,

D.Sc., Professor, Chernihiv National University of Technology, Ukraine

Nataliia Kholiavko,

Ph.D., Associate Professor, Chernihiv National University of Technology, Ukraine

Maksym Dubyna,

Ph.D., Associate Professor, Chernihiv National University of Technology, Ukraine

Olena Zhuk,

Ph.D., Kyiv National Trade and Economics University, Ukraine

\title{
INNOVATION, EDUCATIONAL, RESEARCH COMPONENTS OF THE EVALUATION OF INFORMATION ECONOMY DEVELOPMENT (AS EXEMPLIFIED BY EASTERN PARTNERSHIP COUNTRIES)
}

\begin{abstract}
The global trend of socio-economic development of the leading countries of the world is the formation of an information economy. In conditions of a new type of economy formation, sectors ensuring the country's economic growth and increasing its international competitiveness, capable of generating innovations and conducting high-quality research, play a special role. In this context is increasing the scientific interest in issues of evaluation of information economy development and of determining the influence of research, innovation and educational component on its dynamics. The comparative analysis has shown that in the world practice different methods of such evaluation have been worked out, among which the UN methodology for calculating the Information and Communication Technologies Development Index (IDI) was high lightened within the article. The analytical characterization of the Eastern Partnership countries under the IDI was conducted in the context of its sub-indices. This analysis showed the failure of existing techniques to fully reflect the trends of the information economy in the current turbulent socio-economic conditions. The purpose of the article is to substantiate the methodical approach to the formation of a comprehensive integral indicator of the information economy development with a three-tier structure (educational, innovation, and research components); it is based on the global experience of relevant calculations. The methodical approach includes two stages: a component analysis (calculation of partial indices of educational, innovation, research component of the information economy) and a system analysis (calculation of comprehensive integral index). The proposed approach is tested on the example of Ukraine as a representative of the Eastern Partnership group. On the basis of the index and statistical analysis results the main problem points of the information economy development in the country were identified; and in particular - in the context of a distinct educational, innovation and research component. The authors come to the conclusion about the necessity of development of strategic cooperation of subjects within the Quadruple Helix model (business enterprise sector, higher education sector, government sector and private non-profit sector) to solve identified problems for each component of the information economy.

Keywords: information economy, innovation, higher education, methodical approach, the comprehensive integral indicator of information economy development, indices of educational, innovation, research components.

Introduction. Technological innovations in production, speeding up the technology upgrade, active implementation of ICT, the increase of the science-intensive products cause growth in the demand of economic actors for intellectual resources. Under such conditions, knowledge and information are becoming one of the key factors in the socio-economic development of the country and an important strategic resource for companies. Accordingly, this leads to an increase in the role of higher education and universities in the development of the national economy - as the main producers of highly skilled personnel and generators of knowledge.
\end{abstract}

Cite as: Shkarlet, S., Kholiavko, N., Dubyna, M., \& Zhuk, O. (2019). Innovation, Education, Research Components of the Evaluation of Information Economy Development (as Exemplified by Eastern Partnership Countries). Marketing and Management of Innovations, 1, 70-83. http://doi.org/10.21272/mmi.2019.1-06 

Information Economy Development (as Exemplified by Eastern Partnership Countries)

The beginning of the twenty-first century is marked by the formation within the information society of the so-called information economy (Bell, 1999; Masuda, 1983; Porat, 1977). The information economy we understand as a type of economic system, within which information plays a key role in the development of the main spheres and sectors of the national economy; as an integral part of the implementation of production, distribution, exchange and consumption processes. The further development of this type of economic system is directly related to the creation and implementation of innovations and information technologies in the economic actors' activities.

Information economy puts forward new requirements for ensuring the competitiveness of economic entities. The experience of leading countries (the world's innovative leaders Switzerland, the Netherlands, Sweden, the United Kingdom, Singapore, and the United States) shows that balanced economic growth and global competitiveness growth are determined by the level of preconditions for the development of human capital of the country (Andriessen and Stam, 2004; Davenport, 1999; Schuller, 2007). The quality of human capital (professional competence, qualification level, innovative susceptibility, creative thinking) is determined by the efficiency of higher education institutions functioning. In addition, processes of the information economy formation correlate with the efficiency of universities research activity and the transfer of its results (inventions, scientific developments, advanced technologies, innovative products) into the real sector of the economy (Kwilinski, 2017-2018).

The world community recognizes the significant contribution of higher education to economic development. This is reflected in the inclusion of educational parameters in the methodology for determining the number of international ratings: The Global Competitiveness Index; the Human Development Index; the Innovation Development Index; the ICT Development Index (IDI), etc. In the context of our research, the IDI is of particular interest because it allows determining the level of development of information society and information economy in the country, as well as determining its position in the global economic space.

Studying the IDI methodology in details, the ranking of countries by this index and the dynamics of their constituent sub-indices, we came to the conclusion that it is expedient to formulate a comprehensive approach to evaluate the level of the information economy development. This is substantiated by 1) the urgency of modernization of existing methodological approaches in order to bring them in line with current trends in socio-economic, scientific and technological, and innovative development; 2 ) the expansion of the spectrum of factors influencing the development of the information economy; 3 ) the need to form a specific system of indicators that have an impact on the information economy development.

Literature Review. The issues of development of the information economy are in the focus of research interest of foreign and domestic scientists. Despite numerous advances in the field of peculiarities of the information economy development, the problem of evaluation of its development level remains poorly researched. In our opinion, the deepening needs the identification of the impact of the complex of parameters (particularly - educational, innovation, and research components) on the processes of information economy formation. The information economy transforms approaches to the organization and conduct of business. In the new conditions, is growing the role of intellectual capital in both economic development (Andriessen \& Stam, 2004) and social development of countries (Schuller, 2007). Sullivan P. (1999) considers intellectual capital as an important resource of organizations, and also offers ways to implement the firms' intellectual value. Davenport Th. O. (1999) substantiates the dependence of organizations on the development level of human capital, talents and leadership skills of staff. Formation and development of intellectual capital of the country are carried out by higher educational institutions. The group of researches (lonescu, et al., 2013) proves that the investment in the educational sphere correlates with the standard of living of the population and the level of economic development of the country. The educational component is an integral part of the information economy; it justifies the expediency of evaluation of its impact on the information economy dynamics. 
S. Shkarlet, N. Kholiavko, M. Dubyna, O. Zhuk. Innovation, Education, Research Components of the Evaluation of Information Economy Development (as Exemplified by Eastern Partnership Countries)

In the context of the information economy, universities become the powerful centres which both consolidate strong intellectual capital and generate new knowledge and technological innovations within their research activities. Brenner Th. (2015), on the basis of analysis of the parameters of economic development of 114 countries, proves the impact of research results and innovation output (in particular, patents) on economic growth dynamics. Himenez J. R. (2015) substantiates the high impact of technological change on the dynamics of economic growth in the country. In a joint article, Smoliy et al. (2018), assessed the impact of innovation on economic dynamics in the European Union and Ukraine; the results allowed them to prove the high degree of interconnection between the parameters of innovation and economic development in Europe. Jetter M., et al. (2009) study the impact of technological innovations on the development of business models. Accordingly, it is expedient to consider the role of research and innovation components in the development of the national economy at the current stage of the informatization of society. Modern studies prove that economic growth in the 21 st century requires the development of synergistic interaction between industry and universities. Bekkers R. and Bodas Freitas I. (2008) analyse 23 channels of knowledge transfer between industry and Dutch universities, and they come to the conclusion that it is necessary to deepen cooperation between the business enterprise sector and higher education sector. Specific modernization mechanisms of the industrial sphere of industrial enterprise in conditions of the information economy are proposed by Kwilinski A. (2017, 2018). Ukrainian scholars (Novikova et al., 2018) in a joint article analyse the formation processes of the knowledge-based business environment in higher education institutions of the world; the emphasis is put on the prospects of commercialization of universities' R\&D results in the real sector of the economy. In the analysed context, the Quadruple Helix Concept (Carayannis \& Grigoroudis, 2016) is of particular scientific interest; the Concept is based on expanding cooperation between higher education sector, business enterprise sector, government sector and private non-profit sector. Such a partnership in the modern conditions of the information economy formation creates prerequisites for generating innovations and their transfer and commercialization in the national economy.

The purpose of the article is a substantiation of the methodical approach to the formation of a comprehensive integral indicator of the information economy development that has a three-tier structure and includes educational, innovation, research components.

Methodology and research methods. A range of general scientific and special economic methods are used for the research. Particularly, are used the following general approaches: methods of observation, measurement, abstraction, analysis, synthesis, induction, and deduction. Also, are used special research methods:

- the systematic method - substantiating the general concept of the ICT Development Index methodology, with the details of its individual components, and their interconnection;

- the qualimetric approach - formation the hierarchy of the main components of the comprehensive integral indicator of the information economy development; identification of its specific indicators for calculating the sub-indices;

- the comparative analysis - studying different concepts of evaluation the development level of information society and information economy; identification of similar and different features of the existing approaches;

- the index method - the mathematical description of the approach to determining the comprehensive integral indicator of the information economy development;

- the graphical visualization method - the visual representation of the calculated values of the comprehensive integral indicator of the information economy development and its sub-indices.

The analysis is based on the official statistical databases available in open access. Comparison of the Eastern Partnership countries on the rates of information society development is based on the rating 
S. Shkarlet, N. Kholiavko, M. Dubyna, O. Zhuk. Innovation, Education, Research Components of the Evaluation of Information Economy Development (as Exemplified by Eastern Partnership Countries)

of the International Telecommunication Union (United Nations). The dynamics of the comprehensive integral indicator of the information economy development is calculated on the data of the State Statistics Service of Ukraine. The methodology of the conducted research is organized as follows. Section 1 is devoted to the analysis of world experience in evaluation of the development level of the information society (including aspects of the information economy development as an integral part of the information society), and also identification of advantages and disadvantages of existing methodologies. Section 2 introduces the results of comparative analysis of the countries' disposition by the ICT Development Index (particularly, the Eastern Partnership countries). Section 3 presents the results of the development of the methodical approach to the evaluation of the information economy development. Section 4 introduces the results of the calculation of the integral indicator of the information economy development (on the example of Ukraine as an Eastern Partnership country). Section 5 contains some recommendations for intensification of the information economy development in Ukraine.

Results. The specialized department of the UN ITU (International Telecommunication Union) prepares annually «Measuring the Information Society Report». According to the analytical characteristics of the development of national economies of 176 countries, this report presents their ranking according to the ICT Development Index (IDI). IDI is one of the most comprehensive global indices, compared to the rest of the existing ones; it reflects the countries progress towards the dissemination of the information society and within it - the information economy. The IDI methodology is cumulative, tested and reliable (Fig. 1). The index is integrated and includes 11 indicators grouped into sub-indices: Access sub-index, Use sub-index and Skills sub-index. It is worth noting that IDI structure includes skills sub-index (Fig. 1).

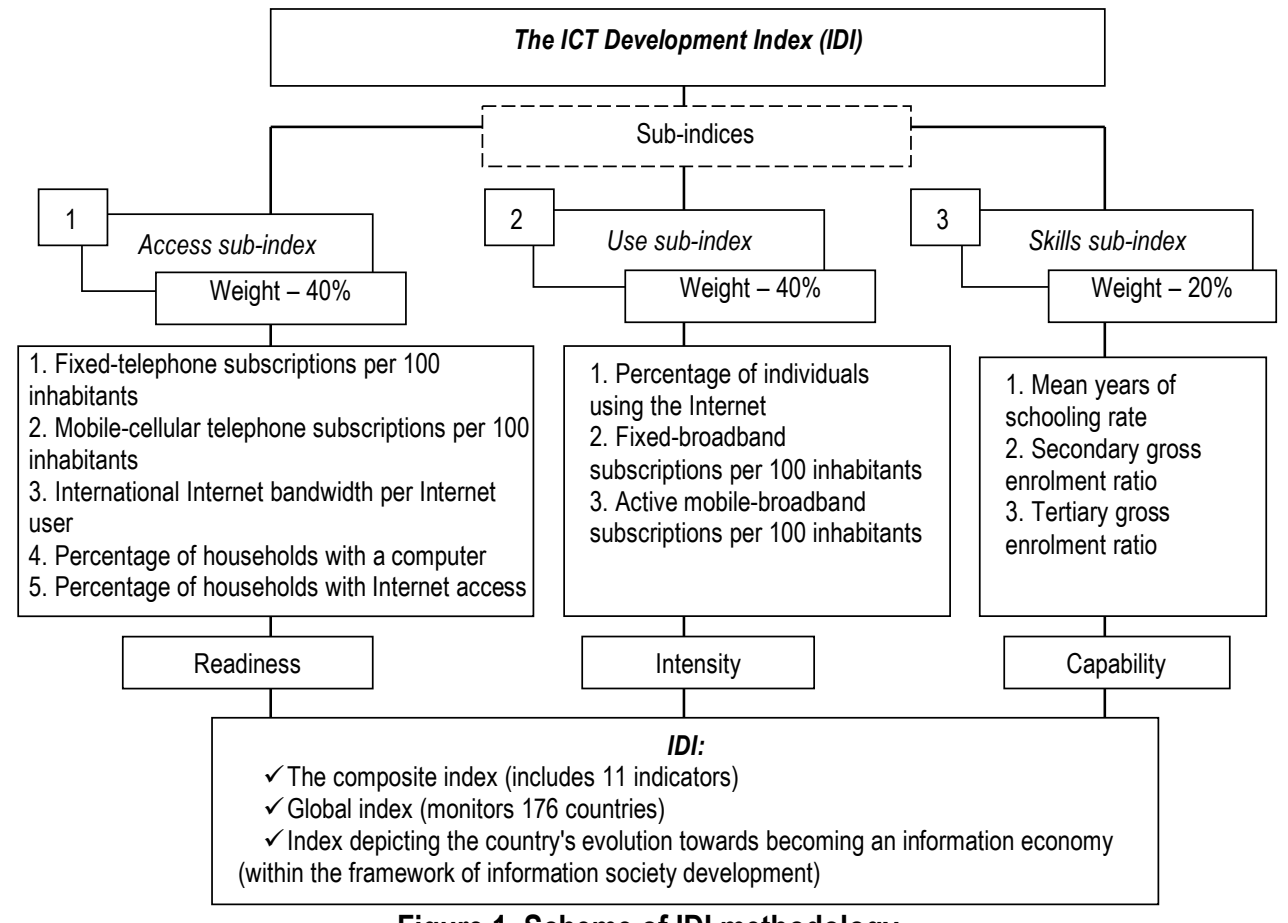

Figure 1. Scheme of IDI methodology

Sources: compiled by the authors on the basis of (The ICT Development Index (IDI): conceptual framework and methodology). 
S. Shkarlet, N. Kholiavko, M. Dubyna, O. Zhuk. Innovation, Education, Research Components of the Evaluation of Information Economy Development (as Exemplified by Eastern Partnership Countries)

Structurally, this sub-index consists of the indicators of the mean years of schooling rate, secondary gross enrolment ratio, and tertiary gross enrolment ratio. In our opinion, the parameters of the educational system development and the efficiency of its subjects' activities (higher education institutions) should necessarily be taken into account when assessing the pace of information society. Education has a decisive influence on human capital development, and accordingly forms the basis of the country's scientific, technological, and innovative development (Sullivan, 1999).

The conducted comparative analysis of the countries by IDI allowed noting that by 2017 the leaders of the rating were Iceland, South Korea, Switzerland, Denmark and the United Kingdom - Fig. 2. The analysis of the dynamics of the national economies demonstrated that the rating leaders are countries with strong and developed economies; countries capable to allocate significant financial resources in support of research, innovation activities and education system development; because the mentioned spheres form the basis for the stable and consecutive development of information and communication technologies, as well as create the preconditions for their introduction into the activities of business entities.

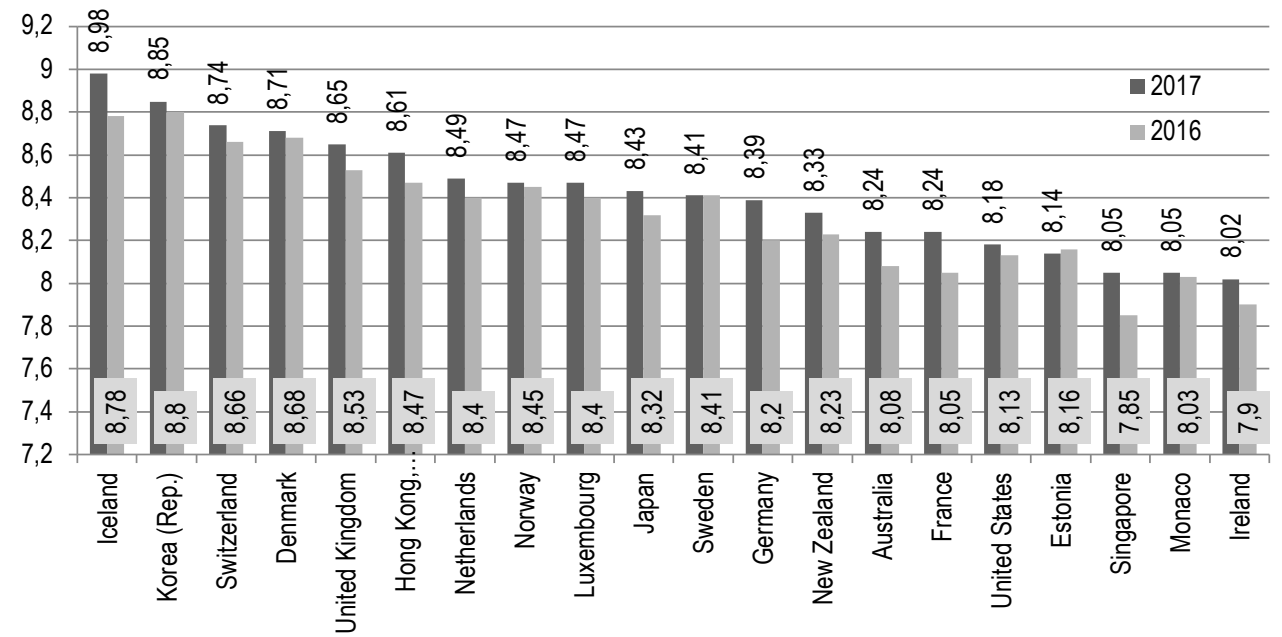

Figure 2. Top-20 countries by IDI, 2016-2017

Sources: compiled by the authors on the basis of (ICT Development Index 2017).

The authors proved that it is more indicative and balanced to comprise the countries according to groups formed on the basis of relative homogeneity of their socio-economic development. Within the framework of this article, the attention is focused on the analysis of the specifics of the influence of groups of factors on the dynamics of the information economy in the Eastern Partnership countries. It should be noted that the Eastern Partnership group is relatively small, includes 6 economically relatively homogeneous countries: Armenia, Azerbaijan, Belarus, Georgia, Moldova, and Ukraine.

As can be seen from the data in Fig. 2, the top-20 leaders by IDI rating do not include countries of the Eastern Partnership group. Within this group, only Belarus is in the top-50 ranking, while the rest ranked under the 59th place (Republic of Moldova). Besides, such ranking was in 2016: the 32nd rank of Belarus; the decrease of positions of Armenia, Georgia, and Ukraine on one point, Azerbaijan - on 5 points; the positive trend in Moldova (moving 4 points up) - Fig. 3. 
S. Shkarlet, N. Kholiavko, M. Dubyna, O. Zhuk. Innovation, Education, Research Components of the Evaluation of Information Economy Development (as Exemplified by Eastern Partnership Countries)

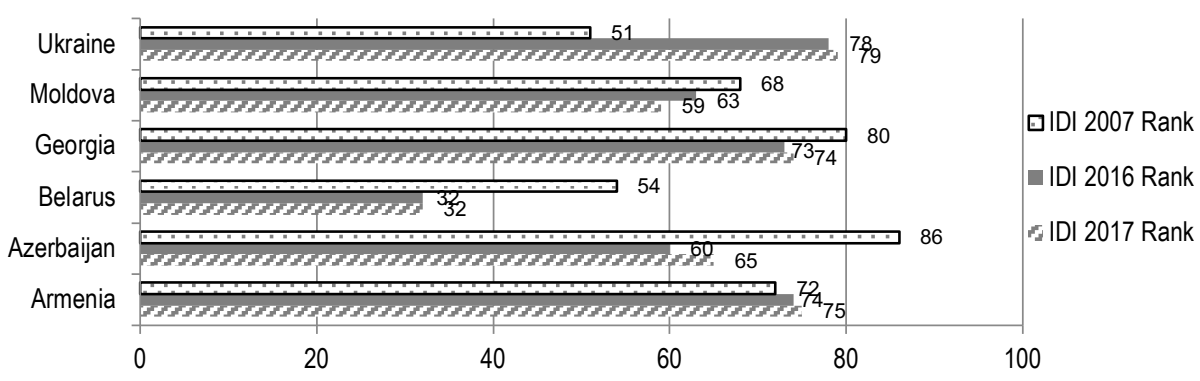

Figure 3. Dynamics of the ranks of the Eastern Partnership countries by IDI

Sources: compiled by the authors on the basis of (ICT Development Index 2017).

More indicative is the dynamics in 10 years:

- the significant decline of Ukraine's rank (from the 51st rank - in 2007 to the $79^{\text {th }}$ - in 2017);

- Armenia lost three points (the $72^{\text {nd }}$ - in 2007, the $75^{\text {th }}$ - in 2017);

- the significant increase of Belarus (from the 54th rank in 2007 to the $32^{\text {nd }}$ - in 2017), Azerbaijan

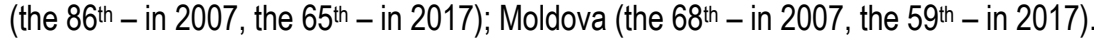

The Eastern Partnership countries disposition in terms of IDI sub-indices is presented in Fig. 4.
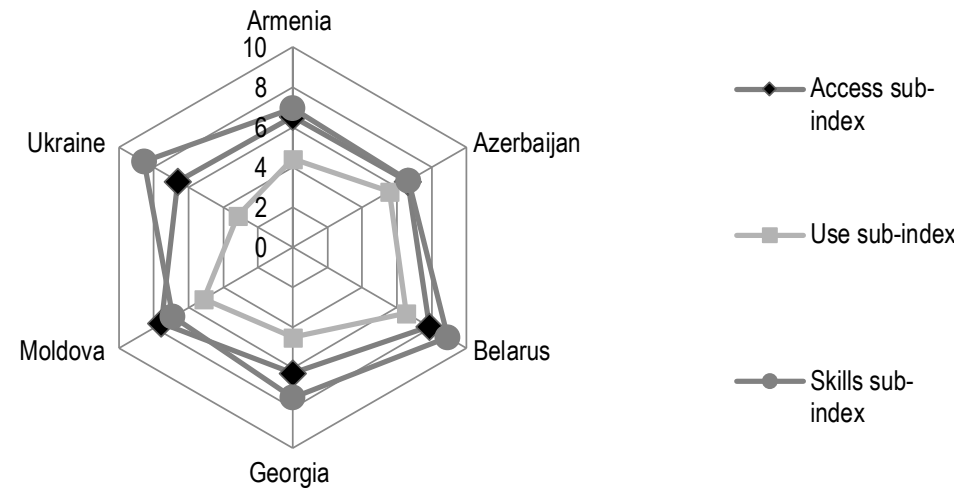

Figure 4. The Eastern Partnership countries disposition in terms of IDI sub-indices, 2017 Sources: compiled by the authors on the basis of (ICT Development Index 2017).

Considering that Belarus is the leader in IDI among the Eastern Partnership countries, we note that its rank is ensured mostly by high parameters of skills sub-index. Noting the data of Fig. 4 , it can be seen that the share of skills sub-index is also high in Ukraine. To deepen the analysis we compiled Table 1 , detailing the structure of IDI sub-indices for the Eastern Partnership countries.

On the results of a detailed comparison of IDI sub-indices, it could come to such conclusions. In current conditions of the information economy formation, the countries' advantages within the analysed rating are being formed in the area of skills sub-index. At the same time positions of the Eastern Partnership counties by indicators «mean years of schooling rate» and "secondary gross enrolment ratio» are nearly the same. It can be explained by the compulsory secondary education and nearly the same period of education duration in these countries. Instead, there are significant differences between 
S. Shkarlet, N. Kholiavko, M. Dubyna, O. Zhuk. Innovation, Education, Research Components of the Evaluation of Information Economy Development (as Exemplified by Eastern Partnership Countries)

the countries' positions by the criteria «tertiary gross enrolment ratio»: $25,48 \%$ - in Azerbaijan; $87,94 \%$ - in Belarus; $82,31 \%$ - in Ukraine.

Table 1. Detailed structure of IDI for the Eastern Partnership countries by its sub-indices, 2017

\begin{tabular}{|c|c|c|c|c|c|c|}
\hline Country & & 高 & & $\pi$ & $\pi$ & \\
\hline Indicator & हू & $\begin{array}{l}\text { : } \\
\text { 胥 } \\
\text { N̦ }\end{array}$ & 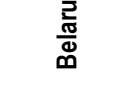 & "ত্ডু & $\frac{\text { 음 }}{\grave{0}}$ & 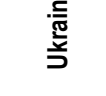 \\
\hline IDI (rank) & 75 & 65 & 32 & 74 & 59 & 79 \\
\hline IDI(value) & 5,76 & 6,2 & 7,55 & 5,79 & 6,45 & 5,62 \\
\hline Access sub-index & 6,52 & 6,62 & 7,87 & 6,26 & 7,56 & 6,6 \\
\hline $\begin{array}{l}\text { Fixed-telephone subscriptions per } \\
100 \text { inhabitants }\end{array}$ & 17,77 & 17,52 & 49,01 & 19,4 & 34,32 & 19,76 \\
\hline $\begin{array}{c}\text { Mobile-cellular telephone } \\
\text { subscriptions per } 100 \text { inhabitants }\end{array}$ & 114,78 & 106,28 & 124,17 & 129,09 & 110,99 & 132,64 \\
\hline $\begin{array}{l}\text { International Internet bandwidth per } \\
\text { Internet user }\end{array}$ & 59859,81 & 34255,14 & 168517,63 & 92145,24 & 144087,44 & 79884,65 \\
\hline $\begin{array}{l}\text { Percentage of households with a } \\
\text { computer }\end{array}$ & 64,71 & 64,3 & 66,96 & 52,5 & 71,0 & 65,1 \\
\hline $\begin{array}{l}\text { Percentage of households with } \\
\text { Internet access }\end{array}$ & 60,50 & 77,4 & 62,46 & 49,79 & 76,0 & 54,79 \\
\hline Use sub-index & 4,42 & 5,55 & 6,54 & 4,47 & 5,12 & 3,17 \\
\hline $\begin{array}{l}\text { Percentage of individuals using the } \\
\text { Internet }\end{array}$ & 62,0 & 78,2 & 71,11 & 50,0 & 71,0 & 52,48 \\
\hline $\begin{array}{l}\text { Fixed-broadband subscriptions per } \\
100 \text { inhabitants }\end{array}$ & 10,13 & 18,58 & 33,3 & 15,81 & 16,33 & 11,99 \\
\hline $\begin{array}{c}\text { Active mobile-broadband } \\
\text { subscriptions per } 100 \text { inhabitants }\end{array}$ & 53,87 & 57,39 & 69,49 & 57,69 & 55,48 & 22,57 \\
\hline Skills sub-index & 6,94 & 6,67 & 8,93 & 7,49 & 6,89 & 8,56 \\
\hline Mean years of schooling rate & 11,3 & 11,2 & 12,0 & 12,2 & 11,9 & 11,3 \\
\hline Secondary gross enrolment ratio & 88,5 & 102,8 & 107,12 & 103,68 & 86,11 & 99,24 \\
\hline Tertiary gross enrolment ratio & 44,31 & 25,48 & 87,94 & 43,42 & 41,21 & 82,31 \\
\hline
\end{tabular}

Sources: compiled by the authors on the basis of (ICT Development Index 2017).

Therefore, Ukraine has the potential to increase its competitive position through the intensification of indicators of skills sub-index (mostly - the tertiary gross enrolment ratio). At the present time, the dynamics of IDI for Ukraine is decreasing.

In this context it should be noted that the European Union defined the 20 deliverables for 2020 to the Eastern Partnership countries, among which are: the harmonization of digital markets (as a component of the information economy); strengthening investment in young people's skills; improving quality and relevance of education systems; integration of Eastern Partnership and EU research and innovation systems. Mentioned above confirm the relevance of evaluation of the impact of educational, innovation and research indicators on the information economy development (Brenner, 2015; Himenez, 2015); that requires the development of a methodical approach.

Constructing the methodical approach to evaluation of the information economy development, we made such prerequisites: a) orientation on modern social and economic, scientific and technical trends of development; b) selection, structuring and optimization of the system of relevant evaluation indicators available in official statistical databases; $c$ ) in-depth analysis of the influence of factors characterizing the educational, innovation and research components of the information economy development. The proposed methodical approach in its basis has the evaluation of a comprehensive integral indicator of the information economy development. 
S. Shkarlet, N. Kholiavko, M. Dubyna, O. Zhuk. Innovation, Education, Research Components of the Evaluation of Information Economy Development (as Exemplified by Eastern Partnership Countries)

The sequence of development and approbation of the methodical approach to the evaluation of the information economy development:

1) structuration of the comprehensive integral indicator: educational component, innovation component, and a research component (Table 2);

Table 2. Component structure of the comprehensive integral indicator of evaluation of the information economy development $\left(l_{i e}\right)$

\begin{tabular}{|c|c|c|c|c|}
\hline $\mathbf{N}$ & Partial indicators & $\begin{array}{l}\text { Sym } \\
\text { bol }\end{array}$ & Unit & $\begin{array}{l}\text { Indicator } \\
\text { weight (by } \\
\text { Saaty } \\
\text { method) }\end{array}$ \\
\hline \multicolumn{5}{|c|}{ I. The index of educational component (ledu) } \\
\hline 1 & Number of higher education institution (III-IV levels of accreditation) & $\mathrm{E}_{1}$ & pcs & 0,06 \\
\hline 2 & $\begin{array}{l}\text { Number of undergraduate students of higher education institution (III-IV levels of } \\
\text { accreditation) }\end{array}$ & $\mathrm{E}_{2}$ & $\begin{array}{l}\text { thous. } \\
\text { persons }\end{array}$ & 0,10 \\
\hline 3 & Number of post-graduate students & $E_{3}$ & person & 0,15 \\
\hline 4 & Number of doctoral students & $\mathrm{E}_{4}$ & person & 0,19 \\
\hline 5 & Amount of consolidated budget expenditures on higher education & E5 & $\mathrm{UAH} \mathrm{mln}$ & 0,19 \\
\hline 6 & Number of higher education institutions with doctoral students & E6 & pcs & 0,09 \\
\hline 7 & Number of higher education institutions with post-graduate students & E7 & pcs & 0,08 \\
\hline 8 & Number of undergraduate students per 10000 & E8 & pcs & 0,14 \\
\hline \multicolumn{5}{|c|}{ II. The index of innovation component (I inn) } \\
\hline 1 & The share of enterprises introducing innovations & $i_{1}$ & $\%$ & 0,10 \\
\hline 2 & Number of introduced new technological processes & $i_{2}$ & pcs & 0,15 \\
\hline 3 & Number of introduced innovation products & $i_{3}$ & pcs & 0,15 \\
\hline 4 & Expenditures on innovation activity of industrial enterprises & $i_{4}$ & $\mathrm{UAH} \mathrm{mln}$ & 0,14 \\
\hline 5 & The share of sold innovative products in the number of industrial ones & $i_{5}$ & $\%$ & 0,14 \\
\hline 6 & Number of agreements on intellectual property rights disposal & $i_{6}$ & Pcs & 0,13 \\
\hline 7 & The share of enterprises engaged in innovations & $i_{7}$ & $\%$ & 0,10 \\
\hline 8 & Number of applications for patenting inventions from national applicants & $i_{8}$ & pcs & 0,09 \\
\hline \multicolumn{5}{|c|}{ III. The index of research component (Isc) } \\
\hline 1 & Number of organizations conducting research and development (R\&D) & $\mathrm{S}_{1}$ & pcs & 0,08 \\
\hline 2 & Number of scientists & $\mathrm{S}_{2}$ & person & 0,10 \\
\hline 3 & Expenditure on R\&D & $\mathrm{S}_{3}$ & UAH mln & 0,15 \\
\hline 4 & The share of R\&D in GDP & $\mathrm{S}_{4}$ & $\%$ & 0,15 \\
\hline 5 & The share of higher education institutions among organizations conducting R\&D & $\mathrm{S}_{5}$ & $\%$ & 0,14 \\
\hline 6 & The share of the higher education sector in R\&D funding & $\mathrm{S}_{6}$ & $\%$ & 0,12 \\
\hline 7 & Number of Doctors of Sciences engaged in economic activities & $\mathrm{S}_{7}$ & person & 0,14 \\
\hline 8 & Number of PhD engaged in economic activities & $\mathrm{S}_{8}$ & person & 0,12 \\
\hline
\end{tabular}

Sources: developed by the authors.

2) identification of the system of partial indicators - for the characteristics of comprehensive index' components (Table 2):

a) educational component (Ionescu et al., 2013; Petrushenko et al., 2017) - indicators characterizing the staffing potential of the information economy development (number and structure of higher education institutions; the number of undergraduate students, postgraduate students, doctoral students; funding of higher education);

b) innovation component (Roper et al., 2008; Jetter et al., 2009) - indicators characterizing the innovative development of national economy as the basis for its informatization (introduction of innovative products and new technological processes; expenditures on innovation activity; applications for patenting inventions; agreements on intellectual property rights disposal; share of innovative active enterprises); 

Information Economy Development (as Exemplified by Eastern Partnership Countries)

c) research component (Zhylinska, 2016; Franses, 2003) - indicators characterizing personnel and financial maintenance of scientific and technological development as a basis of the information economy formation (number of research organizations; the number of scientists; R\&D expenditures; the share of higher education institutions in processes of R\&D implementation and financing);

3) choice of method for constructing a comprehensive indicator. Development of integral indicators could be carried out by the following methods:

- method of multiplication (1). Firstly is needed the accumulation of actual values of selected variables; secondly - the definition of comparison base; thirdly - the calculations.

$$
\mathrm{I}=\prod_{\mathrm{i}=1}^{\mathrm{n}} \mathrm{X}_{\mathrm{i}}
$$

where I - integral indicator; $X_{i}$ - indicator value; $n$ - the number of variable indicators.

- sums method (2):

$$
\mathrm{I}=\sum_{i=1}^{\mathrm{n}} \frac{\mathrm{X}_{i_{1}}}{\mathrm{x}_{i_{0}}}=\sum_{i=1}^{\mathrm{n}} \mathrm{X}_{i}
$$

where $\mathrm{X}_{i_{1}}$ - the value of integral indicator in the current period; $\mathrm{X}_{i_{0}}$ - the value of integral indicator in the base period;

- geometric mean (3):

$$
\mathrm{I}=\sqrt[n]{\prod_{i=1}^{n}=\frac{\Delta \mathrm{X}_{i}}{\mathrm{X}_{i_{0}}}}
$$

where $\Delta X_{i}-$ absolute deviation of the actual value of the integral indicator (in the current period) from its value in the base period.

Since the selected variables are grouped according to certain criteria (components), we have different weight coefficients, so the integral index is calculated as follows (4):

$$
\mathrm{I}=\sqrt{\sum_{i=1}^{n} \mathrm{R}_{\mathrm{j}}\left(\Delta \mathrm{X}_{\mathrm{ij}}\right)^{2}}
$$

where $R_{j}$ - weight coefficient of $\mathrm{j}$ criteria; $\Delta \mathrm{X}_{\mathrm{ij}}$ - absolute deviation of the actual value of integral index $j^{\text {th }}$ criterion (in the current period) from its value in the base period (Kozmenko, 2014).

4) accumulation of statistical data array on identified partial indicators (in dynamics - to ensure the reliability of evaluation);

5) determining the weight of each partial indicator within the components (educational, innovation, research) - on the analytic hierarchy process AHP of Thomas L. Saaty (Saaty, 1980):

- compiling a matrix of pairwise comparisons - for constructing a hierarchy of indicators according to the degree of influence on the components of the comprehensive integral index;

- compiling of calculation tables - for determining weight coefficients (Beshelev \& Gurvych, 1980);

6) formalization of components;

7) normalization of analytical indicators - compiling of a matrix of standardized values by the formula (5): 


$$
\mathrm{z}_{\mathrm{ij}}=\frac{\mathrm{x}_{\mathrm{ij}} \overline{\mathrm{x}_{j}}}{\mathrm{~S}_{\mathrm{j}}}
$$

where $x_{i j}$ - absolute value of indicator in i period; $x_{j}$ - average value of indicator; $s_{j}-$ root-meansquare deviation of $x_{i j}$ indicator (Docenko, 2010; Ovezgeldyev and Petrov, 2002)

8) calculation of partial indices of the comprehensive indicator of the information economy development - in terms of dynamics of three components;

9) calculation of forecast values of partial indices of the comprehensive indicator;

10) development of a comprehensive integral index (on the described above algorithm) - as an average weighted cumulative index of educational, innovation, and research component, with weights identified on basis of the Saaty method (Saaty, 1980).

The proposed methodical approach is aimed at determining the level of the information economy development, while the existing approaches are aimed mainly at monitoring the state of the information society (and only partially include economic aspects). The proposed methodical approach allows evaluating the level of information economy development; identifying the features of educational, innovation and research component of the information economy development; identifying problem points; developing the scientifically grounded recommendations for activating processes of national economy transition to functioning on the informational and innovation basis.

The proposed methodical approach is universal and can be applied by researchers and analysts from different countries. However, one of the main prerequisites for its use is the open access to official statistics, in particular on the indicators included in the structural components of the comprehensive integral indicator. According to mentioned above and taking into account that the authors of the article have open access to statistical bases in Ukraine, Approbation of the developed methodological approach was carried out on the example of Ukraine (as a member of the Eastern Partnership). The results of calculations of the structural components of the proposed comprehensive integral indicator are presented in Table 3.

The first stage of the proposed methodology - component analysis - made it possible to come to the following conclusions. Dynamics of the Index of the research component of the information economy development shows a decline in 2011, which is the result of the global financial and economic crisis of 2008-2009 (the crises led to total savings, including R\&D expenditures). Complication of the geopolitical situation, beginning of hostilities in the East, led to a significant reduction of this Index in 2014-2015.

The high fluctuation is marked by the Index of innovation component. The pace of innovation development correlates with the parameters of the effectiveness of research activities in the country. The problem points outlined above on the Index of research component negatively affect the dynamics of the innovation component. Additionally, it should be emphasized the Index of innovation component's high elasticity, high sensitivity to the change of exogenous factors.

Despite the considerable potential, the forecasting dynamics of educational component demonstrates a negative tendency to decline - in the context of its impact on processes of formation and development of the information economy in the country. The reasons for the forecasting downward dynamics of this Index are: reduction of higher education funding; low level of diversification of universities funding sources; reduction of the number of higher education institutions within the course of optimization of their structure; reduction of the number of students (as a result of impact of demographic and migration factors); insufficient level of practical value and commercial potential of universities' R\&D, etc. 
S. Shkarlet, N. Kholiavko, M. Dubyna, O. Zhuk. Innovation, Education, Research Components of the Evaluation of Information Economy Development (as Exemplified by Eastern Partnership Countries)

Table 3. Results of approbation of methodical approach to evaluation of the information economy development: innovation, research, and educational components

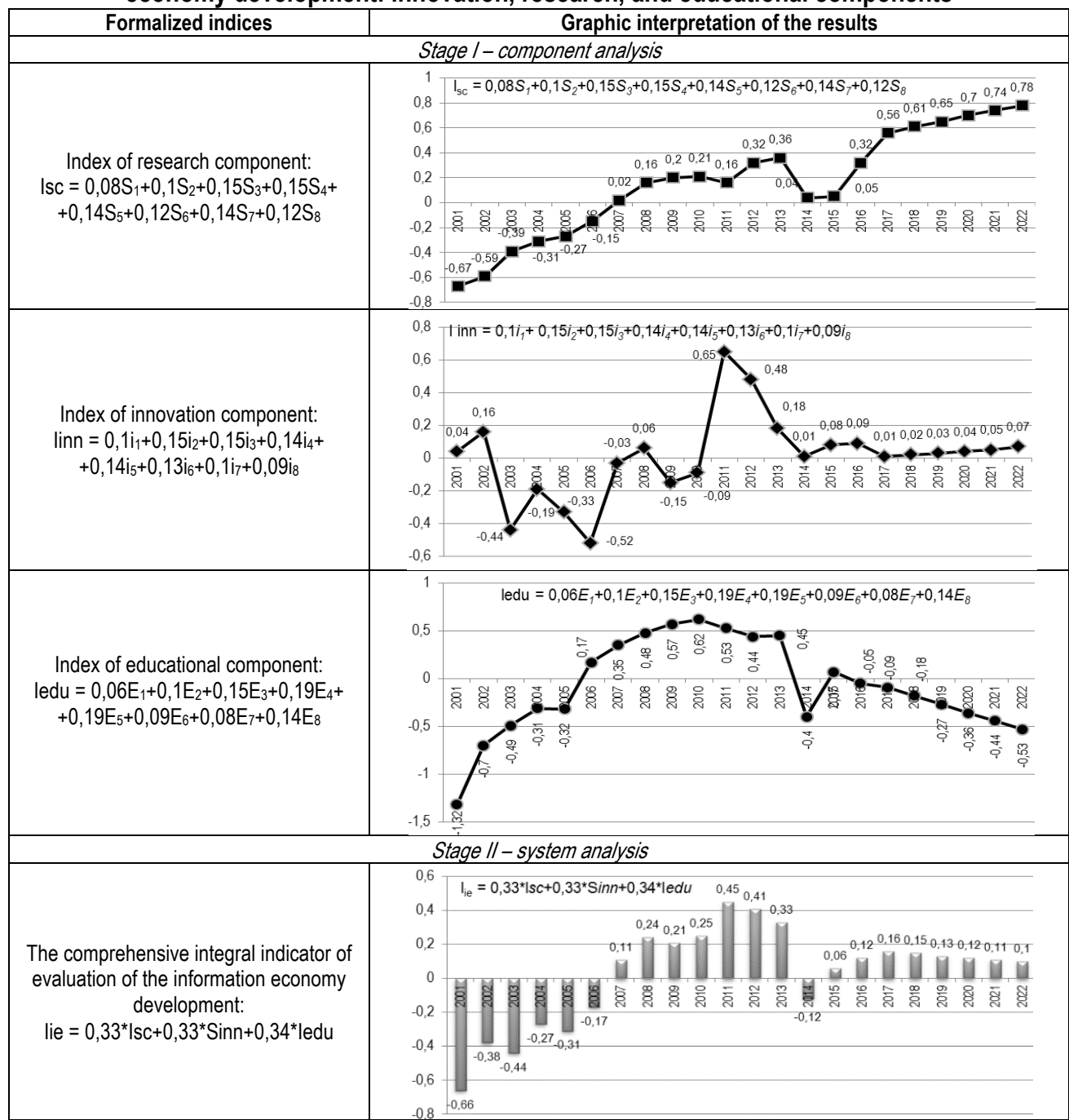

Sources: developed by the authors.

The second stage of the proposed methodology - calculation of the comprehensive integral index allowed making the following conclusions:

- in Ukraine the information economy is only at the stage of its formation;

- the highest correlation is observed between the comprehensive indicator and the partial Index of innovation component;

- the sphere of science demonstrates the significant prospects in information economy development;

- the significant reserves of information economy development are concentrated in the higher education system (modern universities consolidate a country's intellectual capital; generate innovations, make research discoveries and inventions, and also to commercialize them in the national economy; 

Information Economy Development (as Exemplified by Eastern Partnership Countries)

train a new generation of professionals and entrepreneurs, able both to think and act in an innovative way and to adapt to dynamic economic changes).

The analysis of the parameters of the information economy development in Ukraine allowed identifying some problem points: the information economy is only at the formation stage; unsatisfactory level of realization of educational, scientific, and innovation organizations' potential; undeveloped cooperation between business enterprise sector, higher education sector, government sector and private non-profit sector; inefficiency of public financing of higher education, scientific and technical, and innovation activities in the country; undeveloped innovation infrastructure; outdated material and technical base of higher education and research institutions; migration of perspective young people abroad («brain drain»); low prestige of research activity in society; low commercial potential of universities' R\&D results; reduction of global competitiveness of domestic universities; high sensitivity of partial indices of information economy development to the influence the exogenous factors.

The solution of these problems requires the development of scientifically grounded strategic guidelines for enhancing the information economy development on the basis of optimization and effectivization of the existing potential of educational, scientific, and innovative organizations. In our opinion in this context is important to emphases the necessity of interests' synchronization and activities integration within the framework of Quadruple Helix model (business enterprise sector, higher education sector, government sector and private non-profit sector) (Carayannis \& Grigoroudis, 2016; Bekkers \& Bodas Freitas, 2008). Mentioned above will stimulate the development and introduction of competitive innovative research results of universities in the real sector of the national economy, and thus will accelerate the pace of the information economy formation (Skackauskiene et al., 2017; Smoliy et al., 2018; Novikova et al., 2018).

Conclusions. The global trend of socio-economic development of the leading countries of the world is the formation of an information economy. In conditions of a new type of economy formation, sectors ensuring the country's economic growth and increasing its international competitiveness, capable of generating innovations and conducting high-quality research, play a special role. In this context is increasing the scientific interest in issues of evaluation of information economy development and of determining the influence of research, innovation and educational component on its dynamics. The comparative analysis has shown that in the world practice different methods of such evaluation have been worked out, among which the UN methodology for calculating the Information and Communication Technologies Development Index (IDI) was high lightened within the article. The analytical characterization of the Eastern Partnership countries under the IDI was conducted in the context of its sub-indices. This analysis showed the failure of existing techniques to fully reflect the trends of the information economy in the current turbulent socio-economic conditions. The purpose of the article is to substantiate the methodical approach to the formation of a comprehensive integral indicator of the information economy development with a three-tier structure (educational, innovation, and research components); it is based on the global experience of relevant calculations. The methodical approach includes two stages: a component analysis (calculation of partial indices of educational, innovation, research component of the information economy) and a system analysis (calculation of comprehensive integral index). The proposed approach is tested on the example of Ukraine as a representative of the Eastern Partnership group. On the basis of the index and statistical analysis results the main problem points of the information economy development in the country were identified; and in particular - in the context of a distinct educational, innovation and research component. The authors come to the conclusion about the necessity of development of strategic cooperation of subjects within the Quadruple Helix model (business enterprise sector, higher education sector, government sector and private nonprofit sector) to solve identified problems for each component of the information economy. 
S. Shkarlet, N. Kholiavko, M. Dubyna, O. Zhuk. Innovation, Education, Research Components of the Evaluation of Information Economy Development (as Exemplified by Eastern Partnership Countries)

Author Contributions: conceptualization and supervision, S. S.; methodology, M. D. and N. K.; investigation and writing, S. S., N. K. and M. D.; formal analysis and visualization, N. K. and O. Z.; review and editing, S. S.

Funding. This research is carried out within the framework of the scientific project «Integrated Model of Competitive Higher Education in Ukraine under the Quadruple Helix Concept» (№ 0117U007258) with the support of the Ministry of Education and Science of Ukraine.

\section{References}

Andriessen, D.G. \& Stam, C.D. (2004) The intellectual capital of the European Union. URL: www.intellectualcapital.nl/ artikelen/ICofEU2004.pdf.

Bekkers, R. \& Bodas Freitas, I. (2008). Analysing knowledge transfer channels between universities and industry. To what degree do sectors also matter? Research Policy. № 37(10). Pp. 1837-1853.

Bell, D. (1999) The Coming Post-industrial Society. N.-Y.: Basic Books. 507 p.

Beshelev, S.D. \& Gurvych, F.G. (1980) Matematyko-statystycheskye metody ekspertnyx ocenok [Mathematical and statistical methods of expert assessments] $2^{\text {nd }}$ issue. M.: Statistika. 263 p.

Brenner, Th. (2015) Science, Innovation and National Growth. Annual Conference 2015 (Muenster): Economic Development - Theory and Policy, Verein fur Socialpolitik. German Economic Association. URL: http://EconPapers.repec.org/RePEc:zbw:vfsc15:112873.

Carayannis, E. \& Grigoroudis, E. (2016) Quadruple Innovation Helix and Smart Specialization: Knowledge Production and National Competitiveness. Foresight and STI Governance. vol. 10. № 1. Pp. 31-42.

Davenport Th.O. (1999). Human Capital What It Is and Why People Invest It. Jossey-Bass Publishers. San Francisc. P.186. Docenko, O.S. (2010) Praktykum z zagalnoyi teoriyi statystyky [Practical handout on general theory of statistics] Sevastopol: SevNTU. 204 p.

Franses, P.H. (2003) The diffusion of scientific publications. The case of Econometrica 1987. Scientometrics. Vol.56 (1). P. 29-42.

Himenez, J.R. (2015) A non-parametric approach to innovation gaps and economic growth. Journal of Economic and Financial Studies. Issue 5. Pp. 63-69. URL: http://EconPapers.repec.org/RePEc:Irc:lareco:v:3:y:2015:i:5:p:63-69

Ionescu, D. D., Cuza, A. I., Ionescu, A.M., Cuza, A. I. \& Jaba, E. (2013). The Investments in Education and Quality of Life. Journal of Knowledge Management, Economics and Information Technology. Special Issue.

Jetter, M., Satzger, G. \& Neus, A. (2009). Technological Innovation and Its Impact on Business Model. Organization and Corporate Culture - IBM's Transformation into a Globally Integrated, Service-Oriented Enterprise. Business \& Information Systems Engineering. №1. Pp. 37-45.

Kozmenko, O. V. (2014). Ekonomiko-matematycni metody ta modeli (ekonometryka) [Economic-mathematical methods and models (econometrics): a manual. Sumy: Universytetska knyga.

Kwilinski, A. (2017). Development of industrial enterprise in the conditions of formation of information economics. Thai Science Review. Autumn 2017. Pp. 85 - 90. URL: https://doi.org/10.5281/zenodo.1414236

Kwilinski, A. (2018). Mechanism of Modernization of Industrial Sphere of Industrial Enterprise in Accordance with Requirements of the Information Economy. Marketing and Management of Innovations. №4. Pp. 116-128. URL: http://doi.org/10.21272/mmi.2018.4-11.

Masuda, Y. (1983) The Information Society as Postindustrial Society. Washington: Word Future Soc. P. 45.

Novikova, I., Martyniuk, V., Bediukh, A. \& Kharina, O. (2018). Academic capitalism: development trends in Ukraine and European practice. Marketing and Management of Innovations. №1. Pp. 27-44. URL: http://doi.org/10.21272/mmi.2018.1-02

Ovezgeldyev, A.O., Petrov, E.G. \& Petrov, K.E. (2002). Sintez i identyfikatsya modelei mnohofaktornogo otsenivaniya i optimizatsii[ [Synthesis and identification of multivariate estimation and optimization mode/s] Kyiv: Naukova dumka. $164 \mathrm{p}$.

Petrushenko, Yu. M., Vasylieva, T. A., Lyeonov, S. V. \& Vorontsova, A. S. (2017). Investment in the development of a system of long life education as an effective factor of socioeconomic development. Financial and credit activity: problems of theory and practice: collection of scientific works. № 2(23). Pp. 426-436.

Porat, Mark U. (1977) The Information Economy. Nine volumes. Office of Telecommunication, US Department of Commerce. Washington.

Roper, S. Du, J. \& Love, J.H. (2008) Modelling the innovation value chain. Research Policy. № 37(6-7). Pp. 961-977.

Saaty, T. (1980) The Analytic Hierarchy Process. Planning, Priority Setting, Resource Allocation. McGraw-Hill. 345 p.

Schuller, T. (2007) Understanding the social outcomes of learning. Second OECD World Forum on Statistics, Knowledge and Policy. Istanbul, Turkey. June 30. Pp.8.

Skackauskiene, I., Kazlauskiene, E., Katiniene, A. (2017). Modelling Knowledge Synergy Evaluation. Montenegrin Journal of Economics. Vol. 12. № 3. Pp. 35-49. 
S. Shkarlet, N. Kholiavko, M. Dubyna, O. Zhuk. Innovation, Education, Research Components of the Evaluation of Information Economy Development (as Exemplified by Eastern Partnership Countries)

Smoliy, L., Revutska, A. \& Novak, I. (2018). Influence of innovation factor in economic dynamics in Europe. Marketing and Management of Innovations. №1. Pp. 247-258. URL: http://doi.org/10.21272/mmi.2018.1-18

Sullivan, P. (1999) Profiting from intellectual capital. Journal of Knowledge Management. Vol. 3. Issue 2. Pp. 132-143.

Zhylinska, O.I. (2016) Komplementarni efekty` v akty`vizaciyi rozvy`tku naukovo-texnichnoyi diyal'nosti v informacijnomu suspil'stvi [Complementary effects in enhancing the development of scientific and technological activities in the information society] Bulletin of the Taras Shevchenko National Taras Shevchenko University. № 9(186). Pp. 54-60. URL: https://doi.org/10.17721/1728-2667.2016/186-9/1

С. М. Шкарлет, д.е.н., професор, Чернігівський національний технологічний університет (Україна);

Н. І. Холявко, к.е.н., доцент, Чернігівський національний технологічний університет (Україна);

М. В. Дубина, к.е.н., доцент, Чернігівський національний технологічний університет (Україна);

о. С. Жук, к.е.н., Київський національний торговельно-економічний університет (Україна).

Інноваційна, освітня, дослідницька компоненти оцінки розвитку інформаційної економіки (на прикладі країн Східного Партнерства)

Глобальним трендом соціально-економічного розвитку провідних країн світу є становлення інформаційної економіки. В умовах формування економіки нового типу особливу роль у забезпеченні економічного зростання країни та підвищення ії міжнародної конкурентоспроможності відіграють сектори, спроможні до генерації інновацій і проведення високоякісних наукових досліджень. У такому контексті зростає науковий інтерес до питань оцінки рівня розвитку інформаційної економіки та визначення ступеню впливу на його динаміку параметрів дослідницької, інноваційної й освітньої компонент. Компаративний аналіз продемонстрував, що у світовій практиці опрацьовані різні методики подібної оцінки, серед яких у статті виділено методику ОOH з розрахунку Індексу розвитку інформаційно-комунікаційних технологій (IDI). Проведено аналітичну характеристику країн Східного Партнерства за IDI у розрізі його субіндексів. Здійснений аналіз засвідчив неспроможність існуючих методик повною мірою відобразити тенденції розвитку інформаційної економіки в сучасних турбулентних соціально-економічних умовах. Метою статті $\epsilon$ обгрунтування методичного підходу до формування комплексного інтегрального показника оцінки розвитку інформаційної економіки, що має трирівневу структуру (освітня, інноваційна, дослідницька компоненти) і грунтується на світовому досвіді проведення відповідних розрахунків. Даний підхід включає два етапи: компонентний аналіз (розрахунок часткових індексів освітньої, інноваційної, дослідницької компонент інформаційної економіки) і системний аналіз (обчислення комплексного інтегрального показника). Запропонований методичний підхід апробовано на прикладі України як представника групи країн Східного Партнерства. На основі результатів індексного і статистичного аналізу ідентифіковано основні проблемні моменти в розвитку інформаційної економіки в країні, і зокрема - в розрізі виокремлених освітньої, інноваційної і дослідницької компонент. Проведене дослідження дозволило дійти висновків про необхідність розвитку стратегічної співпраці суб'єктів моделі Quadruple Helix (секторів держави, бізнесу, вищої світи, громадськості) для вирішення визначених проблем за кожною із компонент інформаційної економіки.

Ключові слова: інформаційна економіка, інновації, вища освіта, методичний підхід, комплексний інтегральний показник оцінки розвитку інформаційної економіки, індекси освітньої, інноваційної, дослідницької компонент.

Manuscript received: 15.12 .2018$.

(c) The author(s) 2019. This article is published with open access at Sumy State University.

Marketing and Management of Innovations, 2019, Issue 1 